УДК 94(574)

ББК 63.3(5Каз)

\title{
Особенности формирования административно-финансовых институтов в Степном крае (60-90-е гг. XIX в.)*
}

\author{
Ю.А. Лысенко
}

Алтайский государственный университет (Барнаул, Россия)

\section{Features of the Administrative and Financial Institutions Forming in the Steppe Region (60-90 Years of the $19^{\text {th }}$ Century)}

\author{
Yu.A. Lysenko
}

Altai State University (Barnaul, Russia)

На основе анализа делопроизводственных документов Министерства финансов, отложившихся в РГИА, анализируется процесс создания административно-финансовый учреждений - казенных палат и казначейств в Степном крае. Выявлено, что с образованием в 1868 г. Западно-Сибирского генерал-губернаторства часть функций финансовых органов была передана Акмолинскому и Семипалатинскому областным правлениям, другая часть - Семипалатинскому и Акмолинскому казначействам, которые подчинялись казенным палатам Тобольской и Томской губерний. После ликвидации Западно-Сибирского и образования Степного генерал-губернаторства в 1882 г., наряду с Семипалатинской и Акмолинской, в его состав вошла Семиреченская область. При этом ее казначейство сохранило подотчетность казенной палате Туркестанского генерал-губернаторства. Сложившаяся ситуация порождала в Степном крае целый спектр проблем в сфере финансового управления и актуализировала создание полноценной системы административно-финансовых органов. На протяжении 60-80-х гг. XIX в. региональные власти неоднократно обращались в Министерство финансов с соответствующими предложениями, но по тем или иным причинам получали отказ. И только при активном и деятельном участии степного генерал-губернатора Г.А. Колпаковского в 1889 г. было принято решение о создании Омской казенной палаты с подчинением ей всех областных казначейств, функционирующих в Степном крае. В 90-е гг. ХІХ в. в регионе были сформированы и начали действовать уездные казначейства.

Ключевые слова: Российская империя, Степной край, казенная палата, казначейство.
The article analyzes the process of creating administrative and financial institutions: state chambers and treasuries in the Steppe region based on an analysis of the paperwork of the Ministry of Finance deposited in the RSHA (the Russian State Historical Archive). It was revealed that one part of the financial authorities' functions was transferred to the Akmola and Semipalatinsk regional authorities, the other part - to the Semipalatinsk and Akmola treasuries, which were subordinate to Tobolsk and Tomsk provinces treasury chambers during the formation of the West Siberian Governorate General in 1868 . After the liquidation of the West Siberian Governorate General and the formation of the Steppe Governorate General in 1882, along with the Semipalatinsk and Akmola, the Semirechensk Oblast was included in it. At the same time, its treasury remained accountable to the treasury chamber of the Turkestan governorgeneral. The current situation gave rise to a whole range of problems in the sphere of financial management in the Steppe region and actualized the creation of a fullfledged system of administrative and financial bodies. During the $60-80$ s of $19^{\text {th }}$ century the regional authorities repeatedly appealed to the Ministry of Finance with relevant proposals, but for one reason or another were refused. And only with the active participation of the Steppe Governor-General G.A. Kolpakovsky in 1889, they decided to create the Omsk Treasury Chamber, subordinating to it all the regional treasuries operating in the Steppe region. In the 90 s of $19^{\text {th }}$ century county treasuries were formed and began to operate in the region.

Key words: Russian Empire, Steppe region, Treasury Chamber, Exchequer Chamber.

DOI 10.14258/izvasu(2019)6-05

\footnotetext{
^Работа выполнена за счет средств РНФ (проект № 19-18-00180).
} 
Как известно, в России казенные палаты как структурные единицы системы местного самоуправления были учреждены в 1775 г., что вписывалось в общую логику административных реформ последней четверти XVIII в., направленных на унификацию государственного управления в масштабах всей империи. В ведении палаты находился широкий спектр вопросов финансового управления: она осуществляла сбор всех видов государственных налогов, контроль за частной промышленностью и торговлей, источниками государственных доходов - государственными имуществами (природными ресурсами, казенными предприятиями), государственными крестьянами, винными и соляными откупами и подрядами, проводила учетно-статистическую работу по ревизиям (переписям податного населения).

История финансовой системы Российской империи достаточно подробно представлена в советской и новейшей отечественной историографии. Следует назвать прежде всего П.А. Зайончковского, А.Л. Сидорова, А.П. Погребинского и других исследователей, акцентировавших внимание на вопросах формирования нормативно-правовой базы финансовой системы Российской империи, эволюции ее отдельных институтов, состоянии имперских финансов в отдельные исторические периоды [1-4]. Отдельным направлением историографии истории финансовой системы России следует считать ее региональные аспект, связанный с анализом деятельности казенных палат и уездных казначейств в отдельных губерниях империи, региональных моделей налоговых систем [5-8].

Вопросы финансовой политики Российской империи в национальных окраинах представлены в отечественной историографии недостаточно подробно. Как правило, данный спектр проблем рассматривается в общем контексте социально-экономического развития этнорегионов с акцентом на эволюцию региональных налоговых систем [9-12]. Единственной работой, посвященной выявлению и анализу основных моделей финансовых отношений центра и периферии, является исследование Е. Правиловой «Финансы истории: деньги и власть в политике России на национальных окраинах. 1801-1917 гг.». В монографии рассмотрен целый комплекс вопросов формирования финансовых органов, бюджетов, налоговых систем Финляндии, Царства Польского, Закавказья и Туркестанского генерал-губернаторства, определены механизмы участия национальных окраин в финансировании общегосударственных расходов [13]. История формирования и эволюции финансовой системы Степного генерал-губернаторства до сих пор остается за рамками внимания исследователей. На основе документов делопроизводства Министерства финансов, отложившихся в Российском государственном историческом архиве, в данной статье предпринята попытка восполнить данный историографический пробел.

Важным аспектом интеграции центральноазиатских окраин России в общеимперское экономической пространство во второй половине XIX в. являлось формирование в Степном крае и Туркестане финансовой системы и выстраивание отношений имперского центра и региональных органов власти в вопросах бюджетной и налоговой политики, повышения доходности государственных имуществ, участия в финансировании общеимперских расходов и т.д. Процесс институционализации финансовой системы в Центральноазиатском регионе, предполагавший прежде всего создание казенных палат и казначейств, принял специфическую направленность.

Так, в Туркестанском генерал-губернаторстве механизм формирования Туркестанской казенной палаты, областных и уездных казначейств был запущен фактически сразу после его образования. В 1868 г. здесь были созданы местные учреждения Государственного контроля, в 1869 г. - казенная палата и казначейства. Учитывая «отдаленность края от центральных учреждений Министерства финансов», Временным положением об управлении краем, принятым в 1867 г., туркестанскому генерал-губернатору были предоставлены «особые права» по управлению финансами края: право самостоятельно формировать смету доходов и расходов, изменять статьи сметы (не выходя за пределы общей суммы), распределять средства бюджета между военными губернаторами и военноокружными управлениями. Кроме того, ежегодно генерал-губернатору выделялось 200 тыс. руб. на «непредвиденные» расходы, которыми он мог распоряжаться по собственному усмотрению [13, с. 127-128]. Утвержденное в 1886 г. новое Положение об управлении Туркестанским краем приблизило финансовую модель региона к общеимперским стандартам, окончательно распространив здесь общеимперские нормы кассового управления, росписи и финансового контроля и лишив генерал-губернаторов права бесконтрольного распоряжения финансами [13, с. 130].

Процесс формирования административно-финансовых органов в Степном крае - Акмолинской и Семипалатинской областях - реализовывался Министерством финансов по другому сценарию. По Временному положению об управлении ЗападноСибирским генерал-губернаторством 1868 г. управление финансами Акмолинской и Семипалатинской областей оказалось в компетенции двух институциональных структур - казначейств и местных областных правлений. Так, все мероприятия по сбору государственных доходов и производству государственных расходов были возложены в Акмолинской 
области на Омское казначейство с подчинением его Тобольской казенной палате, а в Семипалатинской области - Семипалатинское казначейство с подчинением его Томской казенной палате. Все остальные финансовые компетенции, находившиеся в ведении органов Министерства финансов, были возложены на областные правления Акмолинской и Семипалатинской областей с передачей им функций казенных палат [14, л. 72об.].

Подчинение казенных палат, а вместе с ними и казначейств Министерству финансов, а областных правлений - МВД привело к фактическому разделению финансовой части в Степных областях между данными министерствами. Кроме этого, подотчетность Семипалатинского и Омского казначейств казенным палатам Тобольской и Томской губерний исключала возможность формирования полноценной и внутренне самодостаточной финансовой системы в пределах Западно-Сибирского генерал-губернаторства. Еще одним существенным недостатком реформы 1868 г. являлся тот факт, что по Временному положению об управлении Западно-Сибирским генерал-губернаторством в Акмолинской и Семипалатинской областях не предполагалось создания уездных казначейств. Значительные расстояния между уездными городами степных областей и казначействами в Омске и Семипалатинске делали затруднительным выполнение многих финансовых операций. Все перечисленные факты создавали объективные трудности как в реализации финансовой политики имперских кругов в регионе, так и в решении финансовых вопросов на региональном уровне.

Вполне очевидно, что ситуация, сложившаяся в системе управления финансами Акмолинской и Семипалатинской областей, не могла устраивать региональные органы власти. Поэтому в начале 70-х гг. XIX в. последовало обращение западносибирского генерал-губернатора А.П. Хрущова в Министерство финансов с ходатайством упорядочить в Степных областях финансовую систему. При этом администратор предлагал приблизить ее к общеимперским стандартам, изъяв казначейства Акмолинской и Семипалатинской областей из ведения казенных палат Томской и Тобольской губерний с последующей их передачей либо областным правлениям, либо специально созданной для этого в административном центре Западно-Сибирского генерал-губернаторства - Омске казенной палаты. Для сокращения расходов, которые требовались бы на учреждение палаты в полном составе, А.П. Хрущов проектировал образовать ее «в составе сокращенном, возложив обязанности Управляющего палатой на Управляющего акцизными сборами, а обязанности чиновников особых поручении на акцизных ревизоров» [14, л. 72об.].
Поступившие от генерал-губернатора предложения были рассмотрены в декабре 1877 г. на одном из заседаний Главного управления Западной Сибири. В ходе его была категорически отвергнута идея о сосредоточении финансовой части в местных областных правлениях. Несколько месяцев спустя свое решение по данному вопросу сформировало Министерство финансов, которое поддержало мнение Главного управления Западной Сибири, дополнительно высказавшись категорически против «соединения в одном лице должностей Управляющего казенной палатой и Управляющего акцизными сборами». В результате, ссылаясь на затруднения у Государственного казначейства, связанные с отсутствием финансирования для открытия новых казначейств, Министерство финансов предложило «отложить решение данного вопроса на некоторое время, вместе с ним и проектирование штата будущей казанной палаты» Западно-Сибирского генерал-губернаторства [14, л. 73].

Несколько лет спустя, в 1881 г., генерал-губернатор Западной Сибири Н.Г. Казнаков вновь обратился в Министерство финансов с предложением о реформировании финансовой системы степных областей. Однако и в это раз министерство оказалось не готово к решению проблемы. В официальном ответе оно заявило, «что учреждение Казенной платы для Акмолинской и Семипалатинской областей ввиду последовавшего 17 июля сего (1881. -Ю.Л.) года Высочайшего повеления о сокращении расходов на содержание казенных управлений, не признается возможным» $[14$, л. 73].

Ситуация в сфере финансов еще более осложнилась в связи с созданием Степного генерал-губернаторства в 1882 г. Как известно, в его состав, помимо Акмолинской и Семипалатинской областей, была включена Семиреченская область, в финансовой части подчинявшаяся Туркестанской казенной палате. Таким образом, денежные потоки трех областей Степного края оказались в ведении трех казенных палат, функционировавших за его пределами в Тобольской, Томской губерниях и Туркестанском генерал-губернаторстве. Вполне очевидно, что данная ситуация противоречила общей логике, методам и принципам администрирования в Российской империи, поскольку «по существующим законоположениям, высший надзор по всем частям управления был присвоен генерал-губернатору». Кроме этого, проектировщиками Степного положения 1882 г. вновь был проигнорирован вопрос о создания казначейств в уездных городах края.

В разрешении сложившейся проблемы и поэтапном формировании полноценной институциональной системы административно-финансовых органов Степного генерал-губернаторства деятельное участие принял его первый генерал-губернатор 
Г.А. Колпаковский. По его инициативе была создана специальная комиссия под председательством акмолинского вице-губернатора М. Курбановского, состоявшего при степном генерал-губернаторе чиновника особых поручений Министерства финансов П.Павлова-Сильванского и чиновника особых поручений при степном генерал-губернаторе А. Тюфяева.

Комиссией была проведена тщательная и скрупулезная работа по сбору статической и иной информации, отражающей тенденции, динамику и перспективы экономического развития Степного края. Выявленные данные легли в основу их служебной записки, содержащей целый ряд аргументов в пользу скорейшего открытия в Степном генерал-губернаторстве собственной казенной палаты и сети городских и уездных казначейств.

Прежде всего комиссия делала упор на территориальную отдаленность Омского и Семипалатинского казначейств от Тобольской и Томской казенных палат, а также «дальние расстояния уездных городов от местонахождения Омского и Семипалатинского казначейств». Все это, по заключению комиссии, выступало серьезным препятствием для своевременного «удовлетворения кредиторов казны», внесения налогоплательщиками платежей и взносов «особенно во время разлива рек и беспутицы»; пересылки значительных сумм по почте, сопряженной, с одной стороны, с излишними расходами на страхование денег, ослабляющими кредиты на определенные сметами предметы, а с другой стороны, с «большим риском для казны, как во время следования почты, так и во время хранения сумм на руках третьестепенных распорядителей кредитов» [14, л. 73об.].

Кроме этого, комиссия акцентировала внимание на том, что в условиях отсутствия в уездных городах Степного края казначейств, а вместе с ними специальных помещений для хранения денег, значительные суммы, поступающие в государственный доход, региональные власти вынуждены были хранить в кассах уездных управлений, что также было «сопряжено с немалым риском для казны». По мнению членов комиссии, из-за территориальной отдаленности Семипалатинского и Акмолинского казначейств казна теряла значительную часть доходов «от продажи гербовых марок и бумаги, от подорожных бланков и даже от торговых документов, которых нельзя достать на месте (в уездных городах. - Ю.Л.)». В такой ситуации «имеющие в них надобности, без всякого может быть желания причинить ущерб казне, изыскивают возможные способы обойтись без них» $[14$, л. 73об.].

Не менее важным аргументом комиссии в пользу создания в крае собственных административно-финансовых органов выступал тезис о невозможности для степного генерал-губернатора осуществления «права высшего надзора за финансовыми оборотами управляемого им края». Члены комиссии подчеркивали, что в ситуации, когда «заведование финансовой частью Степного генерал-губернаторства находится в трех казенных платах, совершенно от него не зависящих», ему сложно четко представлять «государственные обороты степных областей», смешивающихся с оборотами Томской, Тобольской губерний и Туркестанского генерал-губернаторства, а вместе в этим «изыскивать способы как к увеличению в крае государственных доходов, так и к уменьшении государственных расходов». Таким образом, в заключении комиссии содержался тезис о том, что сложившаяся ситуация напрямую вредит государственным интересам Российской империи в регионе.

Для подкрепления своих позиций членами комиссии были представлены сведения о движении сумм по Тобольской, Томской губерниям и областям Степного генерал-губернаторства. Из приведенных данных следовало, что на 1883 г. годовая сумма всех оборотов трех областей, входящих в состав Степного края, достигала: по государственным доходам 3516878 руб., по государственным расходам - 6278688 руб., по специальным средствам и партикулярным суммам доходов - 2113310,65 руб., расходов - 1713021,42 руб. Итоговый годовой оборот в Степном крае составил, таким образом, 13621807,75 руб. [14, л. 73об.].

Сумма этих оборотов, по расчетам комиссии, оказалась только на 3147048,87 руб. меньше годовых оборотов Тобольской губернии и Акмолинской области, вместе взятых, и на 713914,84 руб. больше оборотов Томской губернии и Семипалатинской области. Дальнейшее сравнение доходов названных губерний с доходами областей Степного края показало, что главное повышение доходов в Тобольской губернии было связано с питейным и податным налогами, в Томской - с одним питейным налогом. По всем же остальным видам доходов (за исключением табачного, от казенных имуществ и гербового поступления) в Степных областях, в общей сложности, превышали поступления Тобольской губернии на 514546,82 руб., и поступления Томской губернии - на 561881,89 руб. [14, л. 73об.].

Свои прогнозы о неизменном росте денежных оборотов и доходов в Степном крае комиссия строила на целом ряде фактов, основанных на анализе социально-экономической ситуации в регионе. По ее мнению, источниками роста оборотов и доходов могли стать:

1. Увеличение покибиточной подати на 1 руб. с кибитки. В рамках Степного положения 1882 г. размер кибиточной подати для казахского населения составлял 3 руб. с кибитки. Комиссия, указывая на рост благосостояния кочевников, предлагала 
обложить кибитку до 4 руб., «как это практикуется в Семиреченской области». В результате по ее прогнозам доходы Акмолинской области увеличатся на 67 тыс. руб., Семипалатинской на 110 тыс. руб.

2. Обложение налогами русского переселенческого крестьянства. По приведенным сведениям Акмолинского областного правления, в Кокчетавском и Атбасарском уездах Акмолинской области к началу 1880-х гг. XIX в. поселилось 1995 душ крестьян; в Семиреченской области, по данным всеподданнейшего отчета военного губернатора области за 1882 г., «зачислено уже 9000 душ, приселившихся из сибирских и внутренних губерний». В рамках действующего законодательства «все эти крестьяне, по истечении льготного времени, будут обложены установленными окладами», что позволит увеличить доходы региона. Кроме того, комиссия предполагала, что переселение крестьян в степные области «будет принимать со временем все большие размеры» [14, л. 74].

3. Поэтапное налогообложение «оседлых инородцев», переселившихся из китайской провинции Синьцзян на территорию Семиреченской области после передачи Россией Илийского края китайским властям. За пользование земельными наделами и сенокосными угодьями, предоставленными китайским эмигрантам, казна могла получить, по подсчетам комиссии, 73000 руб.

4. Увеличение сборов с недвижимых имуществ и торговых пошлин в Степном крае. Ожидания комиссии были основаны на высочайше утвержденном 26 апреля 1883 г. мнении Государственного совета, в рамках которого был установлен особый ярморочный сбор. На основании того, что в Акмолинской области действовали 25 ярмарок «с привозом на сумму 5501000 руб. и со сбытом на 3275000 руб.», а в Семипалатинской области 15 ярмарок «с привозом на сумму 3790000 и со сбытом - на 2804000 руб.», комиссия заключала, что ее выводы вполне достоверны. В Семиреченской области в условиях отсутствия ярмарок увеличение торговых пошлин прогнозировалось за счет роста внешней торговли [14, л. 74об.].

5. Увеличение налоговых сборов с промышленных и золотодобывающих предприятий. По данным комиссии, в 80-е гг. XIX в. в Степном крае фиксировался рост добывающих и перерабатывающих предприятий. В 1882 г. в Акмолинской области работало 122 кожевенных, овчинных, медеплавильных, мукомольных, салотопенных, свечных, мыловаренных заводов с суммой производства 1729876,3 руб., в Семипалатинской области - 65 предприятий с производством на сумму 97145 руб., в Семиреченской области - 62 предприятия с производством на сумму 160345 руб. [14, л. 74].
Предлагая Министерству финансов принять во внимание тот факт, что «самостоятельные Казенные палаты существуют, например, в Енисейской губернии и некоторых других губерниях Европейской России, обороты которых менее оборотов Степных областей, и что эти последние обороты с каждым годом будут увеличиваться», комиссия делала заключение, что «учреждение особой казенной платы для степных областей не только вполне своевременно, но и необходимо» [14, л. 73об.].

Особое внимание комиссия уделила вопросу открытия уездных казначейств. По ее данным, в Тобольской губернии в 1880-е гг. функционировало 9 казначейств, годовые обороты которых составляли в среднем около 280 тыс. руб.; в некоторых уездных казначействах Томской губернии годовые обороты были чуть более 50 тыс. руб. Поэтому комиссией предлагалось открыть казначейства в уездах Степного края на том основании, что годовые обороты в них значительно превосходят обороты уездов Тобольской и Томской губерний. В Акмолинской области проектировались к открытию казначейства в Петропавловском уезде, годовые обороты которого составляли 403000 руб., в Акмолинском 142000 руб., Кокчетавском вместе с Атбасарским уездом - 185000 руб.; Семипалатинской области в Павлодарском уезде с оборотом в 120000 руб., Каркаралинском - 108000 руб., в Зайсанском 398000 руб. В Семиреченской области предлагалось открыть одно казначейство в Джаркентском уезде. Таким образом, в Степном крае проектировалось открыть семь уездных казначейств [14, л. 75].

Члены комиссии осознавали факт ограниченности ресурсов у Министерства финансов для открытия новых казенных палат и казначейств. Поэтому в ходе своей работы они уделили значительное внимание поиску альтернативных источников финансирования и предложили собственный план решения проблемы. Всего, по заключению комиссии, в Степном крае предлагалось учредить Степную казенную палату в годовым содержанием в 25600 руб., Омское областное казначейство с содержанием 11700 руб., шесть казначейств в Семипалатинской и Акмолинской областях с расходами на содержание 25200 руб. и одно казначейство в Джаркентском уезде Семиреченской области с содержанием штата 4600 руб. Всего, по данным комиссии, на ежегодное содержание полноценной системы административно-финансовых органов Министерства финансов в Степном крае потребовалось бы 67100 руб.

Изыскать данные суммы предлагалось путем сокращения штатов Тобольской, Томской и Туркестанской казенных палат на 15550 руб.; сокращения штатов Акмолинского и Семипалатинского областных правлений, в штате которых были чиновники, выполнявшие функции служащих казенных 
палат, - на 3400 руб.; отмены 10\% выплаты волостным правителям в качестве премиальных, которые они получали раз в три года за бесперебойное поступление покибиточного сбора - 35359 руб. [14, л. 75].

Последним весомым аргументом комиссии в пользу создания отдельной казенной палаты для трех областей Степного генерал-губернаторства стал вопрос о необходимости проведения финансовых ревизий. В период работы комиссии в Степном крае сложилась практика проведения контрольных финансовых ревизий фактически только на основании «письменных официальных сношений». Однако, по мнению членов комиссии, «успех контрольного дела во многом зависел не только от одних письменных официальных сношений», он часто требовал «личных переговоров, знакомства с местными условиями, с постройками, с путями сообщения». Учреждение Степной казенной палаты в Омске и создание в ее структуре Омской контрольной палаты «с возложением на нее ревизии всех оборотных средств Степных областей», могло бы повысить уровень и качество проведения ревизий $[14$, л. 7506.$]$.

Заключения комиссии при степном генералгубернаторе были переданы в Министерство финансов. Несмотря на очевидную рациональность и целесообразность скорейшего создания полноценной системы административно-финансовых органов для Степного края, обсуждение заключения с участием заинтересованных лиц затянулось на несколько лет. Данный факт, на наш взгляд, объясняется несколькими факторами: инертностью центральных органов власти, бюрократическими проволочками, финансовыми трудностями. Только в декабре 1889 г. был подписан указ, по условиям которого для заведования финансовым управлением в Семиреченской, Акмолинской и Семипалатинской областях учреждалась Омская казенная палата [15, с. 15].

В 1890 г. был подписан приказ Министерства финансов о формировании штата Омской казенной палаты. Ее структура определялась на основании закона от 9 июня 1866 г. «О преобразовании Казенных палат и изменении штатов оных в губерниях, управляемых по Общему Губернскому Учреждению». По данному закону Контрольное отделение казенной палаты упразднялось, а его полномочия передавались контрольной палате Государственного контроля Российской империи. В казенной палате учреждались три отделения: казначейское, в функционал которого были переданы вопросы «заведывания вообще счетоводством и отчетностью по приходу и расходу сумм»; ревизское отделение, отвечающее за «ревизские и рекрутские» дела; канцелярия, в ведении которой находились вопросы «личного состава, дела по производству торгов, по наложению взысканий за нарушение Уставов казенного управления». Помимо управляющего и трех отделений, в Омскую казенную палату были назначены столоначальник и его помощник, бухгалтер и его помощник, секретарь, старший чиновник особых поучений, архивариус, всего 24 человек с содержанием в 31400 руб. в год [16, с. 7]. На протяжении 90-х гг. XIX в. в Степном крае были учреждены областные и уездные казначейства.

В заключение отметим, что в рамках имперского законодательства образование в 1868 г. Западно-Сибирского генерал-губернаторства предполагало формирование целостной системы государственных органов управления данной административно-территориальной единицей, в том числе финансовых учреждений - казенных палат и казначейств. Однако по Временному положению об управлении Акмолинской и Семипалатинской областями 1868 г. функции финансово-налоговых органов оказались разделенными между Акмолинским и Семипалатинским областными правлениями и казначействами, с подчинением последних казенным палатам Тобольской и Томской губерний. После ликвидации в 1882 г. ЗападноСибирского и образования Степного генерал-губернаторства, наряду с Семипалатинской и Акмолинской областями, в его состав была передана Семиреченская область. Ее казначейство сохранило свою подчиненность казенной палате Туркестанского генерал-губернаторства.

Сложившаяся ситуация порождала в степных областях целый спектр проблем в сфере финансового управления и актуализировала создание полноценной губернаторской системы административно-финансовых органов. На протяжении 60-80-х гг. XIX в. региональные власти неоднократно обращались в Министерство финансов с соответствующими предложениями, но по тем или иным причинам получали отказ. И только при активном и деятельном участии степного генерал-губернатора Г.А. Колпаковского в 1889 г. было принято решение о создании Омской казенной палаты с подчинением ей всех областных казначейств, функционирующих в Степном крае. В 90-е гг. XIX в. в регионе были сформированы и начали действовать уездные казначейства. 


\section{Библиографический список}

1. Зайончковский П.А. Правительственный аппарат самодержавной России в XIX в. М., 1978.

2. Погребинский А.П. Очерки истории финансов дореволюционной России. М., 1954.

3. Сидоров А.Л. Финансовое положение России в годы первой мировой войны, 1914-1917 гг. М., 1960.

4. История Министерства финансов России: в 4 т. Т. 1: 1903-1917 гг. / гл. ред. А.Л. Кудрин. М., 2002.

5. Дектярев А.Н., Мухамедина Ш. Уфимская казенная плата // Финансы: теория и практика. 2010. № 4.

6. Морозов В.В. Особенности изучения чиновного состава уездных казначейств Нижегородской губернии середины 60-х гг. XIX в. (по данным формулярных списков 1865 г.) // Научные ведомости. 2010. № 7 (78), вып. 14.

7. Семенова Н.Л. Гражданские губернаторы и казенные палаты в системе местного управления Российской империи в конце XVIII - первой трети XIX в. // Известия Самарского научного центра Российской академии наук. 2016. Т. 18, №3.

8. Соловьев Я.В. Московская казенная палата: правовые и организационные основы деятельности в первые годы существования // Вестник Московского государственного областного уни- верситета. Серия: История и политические науки. 2008. №3.

9. Масанов Н.Э. Налоговая политика царизма в Казахстане (20-60-е гг. XIX в.) : автореф. дис. ... канд. ист. наук. Алма-Ата, 1960.

10. Сапелкин А. Налоговая политика царизма в Киргизии (1867-1914) : автореф. дис. ... канд. ист. наук. Фрунзе, 1963.

11. Тунян В.Г. Административная и экономическая политика самодержавия в Закавказье, 1801-1853 : автореф. дис. ... д-ра ист. наук. Тбилиси, 1989.

12. Искандеров А. Социально-экономическое положение Северного Азербайджана в период российских завоеваний (первая треть XIX в.) : автореф. дис. ... канд. ист. наук. Баку, 1992.

13. Правилова Е. Финансы истории: деньги и власть в политике России на национальных окраинах. 1801-1917 гг. М., 2006.

14. Российский государственный исторический архив. Ф. 1396. Оп. 1. Д. 179.

15. Вестник финансов, промышленности и торговли. 1889. №1.

16. Вестник финансов, промышленности и торговли. 1890. №1. 